\title{
A vallásosság szerepe az intenzív osztályon dolgozó orvosok és ápolók véleményének kialakításában az életvégi döntések meghozatalakor
}

\author{
Szücs Orsolya dr. ${ }^{1}$ - Szabó Léna $\mathrm{dr}^{3}{ }^{3}$ - Élő Gábor $\mathrm{dr} .^{2}$ \\ Király Kornél dr. ${ }^{4}$ - Darvas Katalin dr. ${ }^{1,2}$ - Szijártó Attila dr. ${ }^{1}$ \\ Gál János dr. ${ }^{2}$ - Zubek László dr. ${ }^{2}$ \\ ${ }^{1}$ Semmelweis Egyetem, Általános Orvostudományi Kar, \\ Sebészeti, Transzplantációs és Gasztroenterológiai Klinika, Budapest \\ ${ }^{2}$ Semmelweis Egyetem, Általános Orvostudományi Kar, Aneszteziológiai és Intenzív Terápiás Klinika, Budapest \\ ${ }^{3}$ Semmelweis Egyetem, Általános Orvostudományi Kar, II. Gyermekgyógyászati Klinika, Budapest \\ ${ }^{4}$ Semmelweis Egyetem, Általános Orvostudományi Kar, Farmakológiai és Farmakoterápiás Intézet, Budapest
}

Bevezetés: A haldoklást minden korban kulturális és vallási szabályok vették körül, melyek a mai napig hatnak a társadalomban. A 2l. században számos beteg a kórházban, az intenzív osztályon fejezi be életét, ahol nem ritkán kerülhet sor életvégi döntés meghozatalára.

Célkitüzés: Vizsgálatunk célja annak feltárása volt, milyen hatással van az orvosok és ápolók vallásossága a kezeléskorlátozással kapcsolatos döntésekre az intenzív osztályon.

Módszer: Magyarországi intenzív osztályokon dolgozó orvosok és szakdolgozók körében végeztünk kérdőíves felmérést a vallás életvégi döntésekre gyakorolt hatásáról. 189 orvos és 105 ápoló által anonim módon kitöltött kérdőívet elemeztünk.

Eredmények: Az intenzív osztályra történő betegfelvételre nem volt hatással a vallásosság, azonban a szabad ágyak száma a vallásos orvosokat erősebben befolyásolta, mint az ateista és választ nem adó orvosokat $(<0,0001)$. A vallásukat gyakorló orvosok szignifikánsan jobban figyelembe vették a hozzátartozó kérését, mint az ateisták $(\mathrm{p}=0,0002)$. A vallásos ápolók gyakrabban folytatnák a beteg kezelését a hozzátartozó kérése ellenére is, ha még látnának esélyt a gyógyulásra, mint a nem vallásosak.

Következtetés: Vizsgálatunk alátámasztotta, hogy a világnézet befolyásolja az orvosokat és ápolókat az élet végéről hozott döntésekben. A kezeléskorlátozásról hozott döntés összetett, elengedhetetlen megismerni hozzá a beteg és családjának haldoklással kapcsolatos vallási szokásait, mivel jó életvégi döntés a világnézeti szempontok figyelembevétele nélkül nem hozható.

Orv Hetil. 2021; 162(51): 2047-2054.

Kulcsszavak: vallás, életvégi döntés, intenzív osztály

\section{Role of faith in strategies of healthcare professionals in intensive care units in end-of-life decision making}

Introduction: Death has always been surrounded by habits in all ages, influenced by cultural and religious differences. Many patients finish their lives at intensive care units where end-of-life decisions are the part of everyday practice in the 21 th century.

Objective: The goal of our study was to assess how the religious beliefs of physicians and nurses affect their decision on therapy restriction.

Method: We have performed questionnaire-based enquiries among physicians and nurses working at intensive care units on how religion affects end-of-life decisions. We have analyzed the anonymous questionnaires filled out by 189 physicians and 105 nurses.

Results: Our results have confirmed the hypothesis that religion affects decision making about therapy restriction. Patients' admissions were not affected by religious beliefs, but the number of available patient beds influenced the religious physicians more than the atheists ones or the non-responders $(<0.0001)$. Actively religious physicians com- 
plied significantly better with the relatives than atheists $(\mathrm{p}=0.0002)$. Religious nurses would continue patient treatment even against the will of relatives more often than atheists if they see a chance for recovery.

Conclusion: The study supports that religion influences physicians and nurses in their end-of-life decisions. Decisions on therapy restriction are complex; it is important to find out religious beliefs and perception of death among patients and families because good end-of-life decision cannot be made disregarding religious considerations.

Keywords: religiosity, end-of-life decision, intensive care

Szűcs O, Szabó L, Élő G, Király K, Darvas K, Szijártó A, Gál J, Zubek L. [Role of faith in strategies of healthcare professionals in intensive care units in end-of-life decision making]. Orv Hetil. 2021; 162(51): 2047-2054.

(Beérkezett: 2021. május 11.; elfogadva: 2021. június 17.)

\section{Rövidítés}

$\mathrm{DNR}=($ do not resuscitate $)$ nem újraélesztendő

A halál misztériuma ősidők óta foglalkoztatta az emberiséget, minden korban kiemelt hatással volt a vallás a haldoklással kapcsolatos szokásrendre. Az istenhiten alapuló kultúrákban a halott lelke valamilyen formában tovább él, a halált természetes folyamatnak tekintik, könnyebben elfogadják, különféle szertartásokkal veszik körül. $\mathrm{Az}$ ateista emberek szerint az élet a halállal véglegesen megszűnik [1]. Az egyiptomiak bebalzsamozták halottaikat a testük megőrzése céljából; hitük szerint azok lelke átszállt a túlvilágba Ozirisz, a halottak istene elé. A görög mitológiában Nüxnek, az éjszaka istennőjének fia, Thanatosz denevér formájában röpködött, és akinek a hajába kapaszkodott, az meghalt. Nevéból ered az eutanázia szó, melynek jelentése: eu = jó, thanatosz = halál. A halott lelke ezután Kharón ladikján ment az alvilágba. A görög és a római társadalomban is foglalkoztak az élet megrövidítésének gondolatával, a beteg csecsemőket magukra hagyták, elterjedt volt az öngyilkosság is. A filozófusok véleménye eltérő volt a haldoklás megrövidítésével kapcsolatban: Seneca jogosnak tartotta a halál megkönnyítését a szenvedő betegek esetében, Arisztotelész azonban elítélte azt. Hippokratész elvetette az eutanáziát és az öngyilkosságban való segítségnyújtást is, azonban a gyógyíthatatlan betegek kezelését, szenvedésük meghosszabbítását is ellentétesnek tartotta a nil nocere elvével [2]. A római jog bûncselekménynek nevezi az öngyilkossághoz való méregadást, amiért el kell ítélni az orvost [1]. A középkorban gyakran megölték a gyógyíthatatlan betegeket, azonban a kereszténység terjedésével előtérbe került az élet védelme. Szent Ágoston és Aquinói Szent Tamás megbocsáthatatlan bünnek tartotta az öngyilkosságot.

A 20. században az orvostudomány, különösen az intenzív terápia fejlődése számos új erkölcsi kérdést vetett fel az életvégi döntéssel kapcsolatban. A római katolikus egyház több nyilatkozatot is kiadott az élet védelme érdekében: ezek mindegyike tiltja az aktív eutanáziát és az orvosi segítségnyújtást öngyilkosságban, de hangsúlyozza, hogy az életmeghosszabbító eszköz visszautasítása nem tekinthető öngyilkosságnak, illetve eutanáziának. A beteg nem köteles olyan kezelést elfogadni, amely számára túl nagy megterhelést jelent. A kezeléskorlátozásra is szabályt alkotott az egyház: „el lehet utasitani olyan beavatkozásokat, melyek csak egy pislákoló és kinos élet megnyújtását hoznák”, de az arányos eszközök alkalmazása, amelyek a normális kezelés részét képezik, kötelezőek (például: gondozás, folyadékpótlás, fájdalomcsillapítás) [3-5]. A katolikus egyház dolgozta ki a kettős hatás elvét is, mely szerint a jó hatásnak (fájdalomcsillapítás) mellékes következménye a rossz hatás (halál), nem célja. A konzervatívabb protestáns felekezetek a katolikushoz hasonló elveket vallanak.

A zsidó vallás a keresztényhez hasonlóan az élet védelme mellett foglal állást: tilos az aktív eutanázia és az orvosi segítségnyújtás öngyilkossághoz. A kezeléskorlátozással kapcsolatban nincs egységes állásfoglalás: a konzervatív rabbik szerint nem hagyható el életfenntartó kezelés, mások terminális állapotban lévő betegeknél engedélyezik a terápia el nem kezdését. A Halacha szerint folyamatos életfenntartó kezelést nem szabad leállítani, az intermittáló terápia (például dialízis) abbahagyható, mert az a kezelés el nem kezdésének minősül. A táplálék és a folyadék az ember alapszükségletei közé tartozik, így megvonásuk tilos, kivéve, ha adásuk szenvedést okoz $[6,7]$.

Az iszlám vallás sokszínű, tanítása szerint elfogadható a fájdalomcsillapítás, valamint a kezelés el nem kezdése és visszavonása egyaránt terminális állapotú betegeknél, a cél azonban sosem lehet a halál idejének előbbre hozatala. Muszlim betegek rendelkezhetnek az újraélesztés visszautasításáról (do not resuscitate, DNR) is [8]. Az alaptáplálást hitük szerint nem szabad megvonni, amíg a beteg komfortérzetét nem zavarja; az eutanáziát elutasítják.

A hinduizmus szerint a halál módja meghatározó az újjászületésben, jó halál otthon, nyugodt környezetben jön el. Az eutanáziát a törvények tiltják; az erôszakos, korai halált rossznak tekintik, de reménytelen állapotú betegnél a mesterségesen elnyújtott életnek is kis értéke van. A DNR utasítást és a kezelés beszüntetését általában elfogadják. 
A buddhisták az élet többszöri ismétlődésében hisznek, felkészülnek a halálra, de az eutanázia tilos. A fájdalomcsillapítók adása megengedett, de a szedatívumok adása korlátozott, mivel a tiszta tudat megőrzése fontos a halál előtti percekben [9, 10]. Elfogadják a kezelés felfüggesztését, támogatják a hospice-t, nem kötelező a mesterséges táplálás sem. Mivel a világon sokfelé élnek buddhisták, a regionális és kulturális befolyás miatt eltérő szabályok alakultak ki. Kínában a konfucianizmus, a taoizmus és a buddhizmus jellemző, így nincs egységes álláspont az életvégi döntésekben. A halálról keveset beszélnek, az életvégi döntésben a család részvétele rendkívül fontos $[7,11]$.

Japán ősi vallása a sintó, az élet vallása, melynek a 20. században számos új irányzata terjedt el. Nincs tanítása a halál utáni életről, a túlvilágon isteneik laknak. Terminális állapotú betegnél a halál eljövetelét elfogadják, egyik híres mondásuk a „shikata ga nai” - nem lehet segíteni rajta. A másik fó vallás a buddhizmus, emellett elterjedt a konfucionizmus, a taoizmus és a kereszténység is, ezek részletezése azonban meghaladja e publikáció kereteit. Érdekesség, hogy a japán népi hiedelemben a halált tabu övezi, ami miatt a négyes szám kiejtésétől (si) is tartózkodnak, mert kiejtése megegyezik a japán 'halál' szóval.

A mai korban a halál kikerült az otthonokból, az emberek többsége a családtól távol, kórházban, gyakran intenzív osztályon fejezi be életét $[12,13]$. A halál időpontja is mesterségesen szabályozható, kitolható, vagy akár kezeléskorlátozás révén előbbre hozható. Európa lakossága nem homogén a vallási és kulturális hátterét tekintve, így a fent említett vallási szokások ismerete segíthet megérteni mind az orvosok és nővérek, mind a beteg és a család viszonyulását az életvégi döntésekhez.

A világnézet és az életvégi döntések közötti összefüggés összetett kérdés; több tanulmány, köztük a 6 európai országban 142 intenzív osztály bevonásával lezajlott Ethicatt study [14] támasztja alá, hogy a hit hatással lehet mind a beteg, mind a kezelőszemélyzet hozzáállására az életvégi döntésekhez [15-19]. A keleti vallások halállal kapcsolatos eltérő attitüdje konfliktushoz vezethet egy nyugati kórházban [11]. Eltérő vallású vagy ateista orvos is segítséget nyújthat, ehhez célszerü megismerni a beteg vallásának a haldoklással kapcsolatos szokásait, illetve a beteg saját értékrendjét az életvégi döntés meghozatala elött $[12,20,21]$. Két cikk beszámol arról, hogy a Joint Commission (korábban: Joint Commission on the Accreditation of Healthcare Organizations Egészségügyi Szervezetek Akkreditációs Közös Bizottsága ) elvei alapján az egészségügyi személyzet részére egyórás kurzust tartottak az élet végéhez kapcsolódó vallási szokásokról, ezt követendő kezdeményezésnek tartjuk $[8,22]$.

A terápia el nem kezdése jellemzőbb a zsidó, görög, ortodox és muszlim orvosoknál, míg a kezelés visszavonása gyakoribb a keresztény és az ateista orvosok esetében, de regionális különbségek is befolyásolják a döntést $[12,15,23,24]$. Európa déli, többségében hívő katoli- kusok lakta részében ritkább a kezelés visszavonása, mint Európa északi országaiban $[25,26]$. Egy izraeli tanulmány szerint a hívő orvosok kevésbé támogatják a haldoklás aktív megrövidítését [27]. A hívő betegek gyakrabban jelölnek meg helyettes döntéshozót, mint a kevésbé vallásosak [28]. Más tanulmányban azt találták, hogy a vallásnak nincs érdemi hatása az orvosok attitűdjére: az a kulturális környezet a meghatározó, amelyben az orvos felnőtt, erre példa a nagyrészt katolikusok lakta Belgium, ahol ennek ellenére magas az életvégi döntések aránya $[29,30]$.

A jelen tanulmányban kutatócsoportunk az orvosok és a szakdolgozók vallásosságának hatását vizsgálta a kezeléskorlátozásra.

\section{Módszer}

\section{Minta és adatgyüjtés}

A jelen kérdőíves prospektív attitúdvizsgálat része volt annak a Magyarországon 2011-ben végzett felmérésnek, amelyben intenzív osztályon alkalmazott szakdolgozók (szakápolók, diplomás ápolók, általános ápolók) és orvosok véleményét elemeztük az életvégi döntésekkel kapcsolatban. A kérdő́iveket részben elektronikus, részben nyomtatott formában juttattuk el magyarországi egyetemi klinikák, megyei, illetve városi kórházak intenzív osztályain dolgozó orvosoknak és ápolóknak. 189 orvos és 105 ápoló adott önként, névtelenül választ a kérdőívre; nem kerestük meg újra azokat, akik nem válaszoltak.

A kérdőív 21 zárt kérdésból állt, 2 esetben félig nyitott kérdést alkalmaztunk. A kérdőív első felében szerepelt a világnézetre vonatkozó kérdés, ennek függvényében elemeztük az életvégi döntésre vonatkozó kérdésekre adott válaszokat az orvosoknál és az ápolóknál.

A témához kapcsolódó kérdéscsoportokat az alábbiak szerint állítottuk össze:

1) Világnézete:

- hívő, vallását gyakorolja;

- hívő, vallását nem gyakorolja;

- ateista;

- nem nyilatkozik.

2) Befolyásolja-e az intenzív osztályos betegfelvételt:

- a szabad ágyak száma;

- a személyi feltételek;

- a tárgyi feltételek;

- a beteg/hozzátartozó kérése?

3) A kezelés korlátozását befolyásolja:

- a szabad ágyak száma;

- a személyi feltételek;

- a tárgyi feltételek.

4) A kezeléskorlátozásról hozott döntést megalapozza:

- a beteg kívánsága;

- a hozzátartozó kívánsága;

- a beteg aktuális állapota;

- a beteg hosszú távú életminősége;

- az ápolók véleménye. 


\section{5) Tájékoztatásra vonatkozó kérdések:}

- Mit tenne, ha a beteg vagy hozzátartozója kívánná a kezelés felfüggesztését, de Ön még látna esélyt?

- Mit tenne, ha már nem látna esélyt betege gyógyulására?

A válaszadók a kérdések egyik felében Likert-skála segítségével határozták meg, mennyire játszanak fontos szerepet a feltüntetett szempontok a gyakorlatban $(\mathrm{Li}-$ kert-skála: 0: egyáltalán nem, 5: nagyon fontos szempont).

A 2011-ben történt népszámlálási adatok alapján [31] a magyarországi lakosok 38,96\%-a római katolikus, $13,77 \%$-a protestáns, $0,11 \%$-a izraelita, $0,138 \%$-a ortodox, 0,056\%-a iszlám vallású, 0,098\%-a buddhista, 1,68\%-a egyéb felekezetú, 18,2\%-a nem tartozik egyik felekezethez sem, ebből 1,5\% vallotta magát ateistának. $27,16 \%$ nem adott választ a vallásra vonatkozó kérdésre.

\section{Statisztikai elemzés}

A statisztikai elemzést a GraphPad Prism 5.0 programmal (GraphPad Software, San Diego, CA, USA) végeztük; Mann-Whitney-féle U-próbát, Student-féle t-tesztet, Kruskal-Wallis-varianciaanalízist és Dunn-féle post hoc tesztet használtunk. Statisztikailag szignifikánsnak a $\mathrm{p}<0,05$ szintet fogadtuk el.

\section{Eredmények}

A válaszadási arány $13 \%$ volt, így a vizsgálat nem tekinthető reprezentatívnak.
1. táblázat |A vallásosság megoszlása (az értékek \%-ban vannak feltüntetve)

\begin{tabular}{lll}
\hline Világnézet & Ápolók $(\mathrm{n}=105)$ & Orvosok $(\mathrm{n}=189)$ \\
\hline Hívő & $14(13,3 \%)$ & $48(25,4 \%)$ \\
Nem gyakorló hívő & $42(40 \%)$ & $77(40,7 \%)$ \\
Ateista & $18(17,1 \%)$ & $30(15,9 \%)$ \\
Nem nyilatkozik & $31(29,5 \%)$ & $34(18 \%)$ \\
\hline
\end{tabular}

\section{Az 1. kérdéscsoportra adott válaszok eredményei}

A vallásosságra vonatkozó kérdésre az ápolók közül 14en mondták magukat gyakorló hívő́nek (13,3\%), 42-en nem gyakorló hívőnek (40\%), 18-an ateistának (17,1\%); 31-en nem adtak választ $(29,5 \%)$. Az orvosok közül 48 gyakorló (25,4\%), 77 nem gyakorló hívő $(40,7 \%), 30$ ateista volt $(15,9 \%) ; 34$-en nem válaszoltak erre a kérdésre (18\%) (1. táblázat).

\section{A 2-4. kérdéscsoportra adott válaszok eredményei}

Az intenzív osztályra történő betegfelvételnél a szabad ágyak száma a hívő orvosokat erősebben befolyásolta, mint a választ nem adókat $(\mathrm{p}<0,0001)$. Ennek hátterében az állhat, hogy amennyiben nem áll rendelkezésre üres ágy, az új beteg felvétele miatt egy már kezelt beteg sorsáról is döntést kell hozni (2. és 3. táblázat). A kezeléskorlátozást befolyásoló személyi és tárgyi feltételek megítélése és a vallásosság között nem találtunk összefüggést egyik csoportban sem, azonban az orvosok ese-

2. táblázat A vallásosság hatása a betegfelvételre és a kezeléskorlátozásra. Az ápolók Likert-skála (0-5) segítségével határozták meg, egyetértenek-e azzal, hogy a fenti faktorok szerepet játszanak a döntéshozatalban. Kruskal-Wallis-teszttel a különböző csoportok között szignifikáns különbség nem igazolódott. Átlag- (mean) értékeket tüntettünk fel

\begin{tabular}{|c|c|c|c|c|c|}
\hline \multirow{2}{*}{$\begin{array}{l}\text { Ápolók }(\mathrm{n}=105) \\
\text { Kezeléskorlátozásra vonatkozó kérdések }\end{array}$} & \multicolumn{5}{|c|}{ Világnézet } \\
\hline & $\begin{array}{c}\text { Hívő } \\
(\mathrm{n}=14)\end{array}$ & $\begin{array}{l}\text { Nem gyakorló hívő } \\
(\mathrm{n}=42)\end{array}$ & $\begin{array}{l}\text { Ateista } \\
(\mathrm{n}=18)\end{array}$ & $\begin{array}{l}\text { Nem nyilatkozott } \\
\quad(\mathrm{n}=31)\end{array}$ & p-érték \\
\hline \multicolumn{6}{|l|}{ Betegfelvétel } \\
\hline A szabad ágyak száma & $3,86(1,79)$ & $3,10(1,84)$ & $3,67(1,65)$ & $3,23(2,03)$ & 0,3921 \\
\hline Személyi feltételek & $2,57(2,03)$ & $2,39(1,73)$ & $3,12(1,62)$ & $2,3(1,99)$ & 0,4643 \\
\hline Tárgyi feltételek & $3,00(1,80)$ & $2,85(1,673)$ & $2,72(1,81)$ & $2,42(1,96)$ & 0,7373 \\
\hline A beteg kérése & $2,67(1,92)$ & $2,54(1,58)$ & $2,83(1,76)$ & $2,29(1,66)$ & 0,6742 \\
\hline \multicolumn{6}{|l|}{ A kezelés korlátozása } \\
\hline A szabad ágyak száma & $2,36(1,86)$ & $2,28(1,60)$ & $3,17(1,58)$ & $2,43(1,85)$ & 0,2857 \\
\hline Személyi feltételek & $1,79(1,63)$ & $1,98(1,64)$ & $2,39(1,65)$ & $1,97(1,61)$ & 0,7203 \\
\hline Tárgyi feltételek & $2,14(1,66)$ & $1,925(1,51)$ & $2,65(1,62)$ & $1,87(1,53)$ & 0,3478 \\
\hline A beteg kérése & $2,57(1,70)$ & $2,49(1,37)$ & $2,11(1,41)$ & $1,96(1,77)$ & 0,4392 \\
\hline A hozzátartozó kérése & $2,36(1,78)$ & $2,74(1,52)$ & $2,71(1,45)$ & $2,56(1,74)$ & 0,8926 \\
\hline A beteg aktuális állapota & $3,43(1,70)$ & $3,46(1,32)$ & $3,5(1,26)$ & $3,86(0,97)$ & 0,6814 \\
\hline A beteg hosszú távú életminősége & $2,57(1,79)$ & $3,13(1,67)$ & $3,28(1,40)$ & $3,07(1,46)$ & 0,6814 \\
\hline Az ápolók véleménye & $2,36(1,87)$ & $1,80(1,59)$ & $2,47(1,74)$ & $2,32(1,68)$ & 0,4261 \\
\hline
\end{tabular}


3. táblázat | A vallásosság hatása a betegfelvételre és a kezeléskorlátozásra. Az orvosok Likert-skála (0-5) segítségével határozták meg, hogy a fenti faktorok menynyire befolyásolták a döntéshozatalt. Átlag- (mean) értékeket tüntettünk fel

\begin{tabular}{|c|c|c|c|c|c|}
\hline \multirow{2}{*}{$\begin{array}{l}\text { Orvosok }(\mathrm{n}=189) \\
\text { Kezeléskorlátozásra vonatkozó kérdések }\end{array}$} & \multicolumn{5}{|c|}{ Világnézet } \\
\hline & $\begin{array}{c}\text { Hívő } \\
(\mathrm{n}=48)\end{array}$ & $\begin{array}{l}\text { Nem gyakorló hívő } \\
\qquad(\mathrm{n}=77)\end{array}$ & $\begin{array}{c}\text { Ateista } \\
(\mathrm{n}=30)\end{array}$ & $\begin{array}{l}\text { Nem nyilatkozott } \\
\quad(\mathrm{n}=34)\end{array}$ & p-Érték \\
\hline \multicolumn{6}{|l|}{ Betegfelvétel } \\
\hline A szabad ágyak száma & $3,29(1,37)$ & $3,39(1,29)$ & $2,87(1,36)$ & $2,12(1,27)$ & ${ }^{1}<0,0001$ \\
\hline Személyi feltételek & $2,17(1,48)$ & $2,09(1,57)$ & $1,63(1,03)$ & $1,71(1,53)$ & 0,2788 \\
\hline Tárgyi feltételek & $2,31(1,31)$ & $2,19(1,40)$ & $1,87(1,31)$ & $2,03(1,61)$ & 0,5145 \\
\hline A beteg kérése & $3,36(1,58)$ & $2,92(1,45)$ & $3,46(1,5)$ & $2,70(1,72)$ & 0,0796 \\
\hline \multicolumn{6}{|l|}{ A kezelés korlátozása } \\
\hline A szabad ágyak száma & $2,40(1,76)$ & $2,52(1,55)$ & $2,31(1,76)$ & $1,44(1,48)$ & ${ }^{2} 0,0173$ \\
\hline Személyi feltételek & $1,56(1,60)$ & $1,52(1,47)$ & $1,29(1,18)$ & $0,85(1,13)$ & 0,0963 \\
\hline Tárgyi feltételek & $2,13(1,50)$ & $1,74(1,38)$ & $2,10(1,42)$ & $1,47(1,52)$ & 0,1101 \\
\hline A beteg kérése & $2,98(1,45)$ & $2,51(1,48)$ & $2,57(1,97)$ & $2,52(1,69)$ & 0,4405 \\
\hline A hozzátartozó kérése & $3,00(1,32)$ & $2,19(1,36)$ & $1,87(1,57)$ & $1,58(1,57)$ & ${ }^{3} 0,0002$ \\
\hline A beteg aktuális állapota & $3,60(1,17)$ & $3,60(1,23)$ & $4,17(0,95)$ & $3,81(1,55)$ & 0,0559 \\
\hline A beteg hosszú távú életminősége & $3,81(1,25)$ & $3,87(1,05)$ & $3,87(1,33)$ & $3,66(1,43)$ & 0,9378 \\
\hline Az orvosok véleménye & $2,67(1,24)$ & $2,26(1,33)$ & $2,35(1,65)$ & $2,12(1,55)$ & 0,3063 \\
\hline
\end{tabular}

${ }^{1}$ Világnézetükről nem nyilatkozó ps. hívő (gyakorló és nem gyakorló) orvosok

${ }^{2} \mathrm{Nem}$ gyakorló hívő ps. nem nyilatkozók

${ }^{3}$ Gyakorló hívő́k vs. többi csoport

tében a kezeléskorlátozást befolyásoló faktorok közül a szabad ágyszám szignifikánsan erősebb korlátozó tényezőnek bizonyult a vallásukat nem gyakorló hívők körében, mint a választ nem adóknál $(\mathrm{p}=0,017)$. A gyakorló hívő orvosok szignifikánsan jobban figyelembe vették a belátási képességgel nem rendelkező beteg hozzátartozójának kérését, mint az ateisták és a nem válaszolók ( $\mathrm{p}=0,0002)$ (3. táblázat).

$\mathrm{Az}$ ápolók világnézete nem befolyásolta a betegfelvételről, illetve a megkezdett kezelés korlátozásáról alkotott véleményüket.

A Dunn-féle post hoc teszttel végzett alcsoportelemzés során azt találtuk, hogy a gyakorló hívő orvosok esetében a kezeléskorlátozásról hozott döntést erösebben befolyásolja a hozzátartozó kívánsága, mint a nem gyakorló hívő és ateista orvosoknál ( $\mathrm{p}=0,0002$ a teljes tesztre) (1. ábra).

\section{Az 5. kérdéscsoportra adott válaszok eredményei}

A következő két kérdésben arra kerestük a választ, hogy milyen mértékben tájékoztatnák a beteget az orvosok az életvégi döntésről, illetve az ápolók egyetértenek-e a tájékoztatással, figyelembe veszik-e kérésüket, mit tennének, ha a kezeléskorlátozás szükségességéről hozott véleményük különbözne a betegétől. Mit tenne, ha a beteg vagy hozzátartozója kivánná a kezelés felfüggesztését, de Ön még látna esélyt? (4. táblázat)

Egyéb: a válaszadók saját szavaikkal fogalmazták meg, mit tennének ebben a helyzetben (például nem az ő kompetenciája a döntéshozatal, konzultálnának más kollégával).

A kérdés az ápolók hozzáállását dolgozta fel, a hozzátartozók tájékoztatása nem ápolói kompetencia. Khinégyzet-próbával szignifikáns különbséget találtunk a hívő, a vallását nem gyakorló hívő és az ateista ápolók között $(\mathrm{p}=0,04)$. Az ápolók jelentős része tájékoztatná a beteget, ezután fele-fele arányban folytatnák, illetve függesztenék fel a kezelést (44,7 vs. 44,7\%). Az ápolók

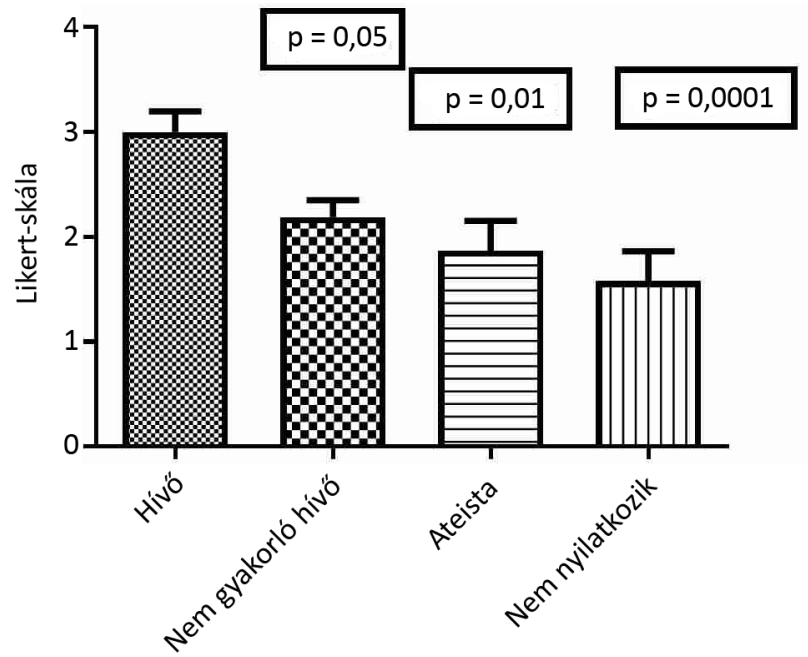

\begin{tabular}{l|l} 
1. ábra & Mennyire alapozza meg a kezeléskorlátozásról hozott döntést
\end{tabular} a döntésképtelen állapotú beteg hozzátartozójának kérése? A p-értékek a gyakorló hívő orvos és a többi csoport közti szignifikanciát mutatják 
Mit tenne, ha a beteg kívánná a kezelés felfüggesztését, de Ön még lát esélyt?

\begin{tabular}{llll}
\hline & $\begin{array}{l}\text { Tájékoztat, } \\
\text { felfüggeszt }\end{array}$ & $\begin{array}{l}\text { Tájékoztat, } \\
\text { tovább kezel }\end{array}$ & Egyéb \\
\hline $\begin{array}{l}\text { Ápolók } \\
(\mathrm{n}=105)\end{array}$ & $47(44,76 \%)$ & $47(44,76 \%)$ & $11(10,47 \%)$ \\
$\begin{array}{l}\text { Orvosok } \\
(\mathrm{n}=189)\end{array}$ & $78(41,71 \%)$ & $102(54,54 \%)$ & $7(3,74 \%)$ \\
\hline
\end{tabular}

10,47\%-a erre a részben nyílt kérdésre azt válaszolta, hogy nem tartozik a kérdés az ő kompetenciájába. Az orvosok 54,54\%-a tájékoztatást követően folytatná, 41,71\%-a felfüggesztené a kezelést a beteg kérésére. Az orvosok esetében nem találtunk ennél a kérdésnél szignifikáns különbséget (2. ábra).

Az orvosok világnézete szignifikánsan befolyásolta az általuk gyógyíthatatlannak vélt betegek esetében választott megoldást: khi-négyzet-próba $(\mathrm{p}=0,0012)$.

A megkérdezett orvosok válaszai alapján az ateisták gyakrabban vonják vissza a kezelést a hozzátartozók értesítése nélkül, mint a többi csoport, másrészről a vallásukról nem nyilatkozó orvosok arányaikban nagyobb számban folytatnák a kezelést a beteg vagy a hozzátartozó informálásának hiányában is.

A vizsgálat egyértelműen pozitív eredménye, hogy mind az ápolók, mind az orvosok többsége $(84 \%$ vs. $83,8 \%$ tájékoztatná a beteget/hozzátartozóját az életvégi döntés meghozatala előtt. Az ápolók mindössze 5\%-a nem ért egyet a beteg tájékoztatásával, közülük is csupán az ápolók 1\%-a (1), az orvosok 2,1\%-a (4) (ebból 3 ateista) függesztette volna fel a kezelést felvilágosítás nélkül.

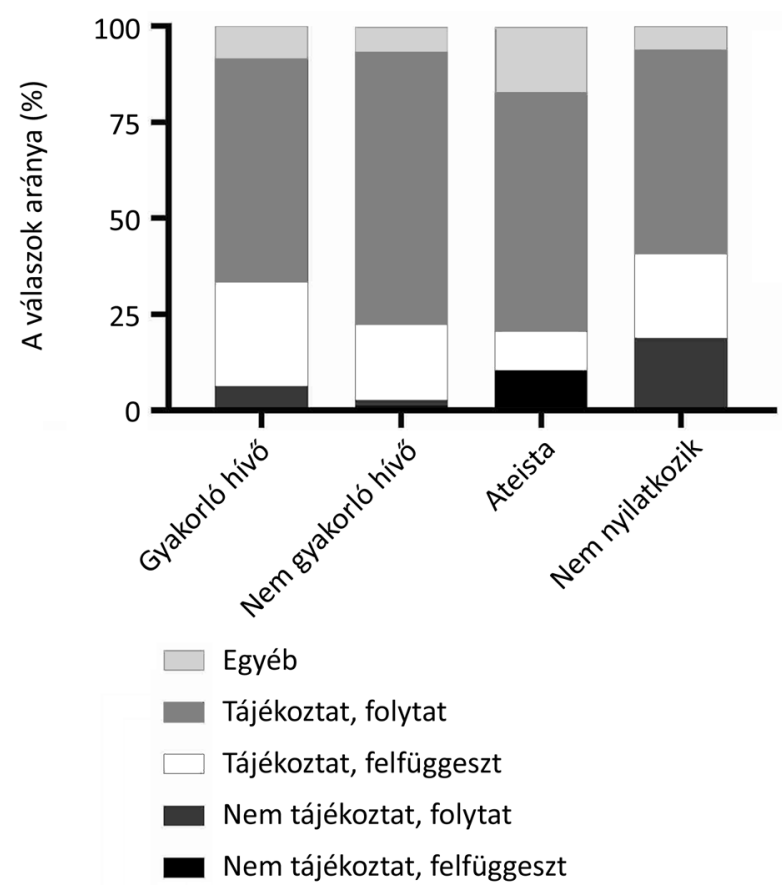

2. ábra

Az orvosok válaszainak százalékos megoszlása az alábbi kérdésre: Mit tenne, amennyiben nem látna esélyt a beteg gyógyulására?

\section{Megbeszélés}

A betegek intenzív osztályos felvételéről hozott döntés orvosi kompetencia. Vizsgálatunkban az ápolók véleményét is megkérdeztük azzal a céllal, hogy megismerjük hozzáállásukat a fenti kérdésekhez. Az Ethicatt study nem talált szignifikáns különbséget az intenzív osztályra történő betegfelvétel és a vallásosság között sem az orvosok, sem az ápolók esetében [14]. Ezt saját vizsgálatunk részben támasztja alá, a betegek intenzív osztályos felvételét nem befolyásolta a szakdolgozók vallásossága. Az orvosok esetében azonban a vallásukat gyakorló és nem gyakorló hívők egyaránt fontosabb tényezőnek érezték a szabad ágyak számát, mint a választ nem adók. Hasonlót figyeltünk meg a kezeléskorlátozást befolyásoló faktorok vizsgálatakor: az ápolók esetében nem volt különbség a vallás tekintetében, a nem gyakorló hívő orvosokat viszont erősebben befolyásolta a szabad ágyak száma. Emellett a vallásos orvosok szignifikánsan jobban figyelembe vették a hozzátartozók kezeléskorlátozással kapcsolatos véleményét, mint az ateista orvosok ( $\mathrm{p}=$ $0,0002)$.

Az életfenntartó kezelések korlátozása rendkívül öszszetett, konszenzuális döntés eredménye; javasolt bevonni a beteg kezelésében részt vevő társszakmák képviselőit és az ápolókat is a maguk kompetenciaszintjének megfelelően, emellett a hozzátartozók részvétele is fontos, hiszen ők ismerik a beteg preferenciáit. Vizsgálatunk következő részében arra kerestük a választ, befolyásolja-e a kezeléskorlátozásról hozott döntést a vallásosság. Az Ethicatt study eredményei azt mutatják, hogy a hívő orvosok szívesebben folytatják a kezelést, és kevésbé támogatják a halál idejének előbbre hozatalát a terminális állapotú betegek esetében [14]. Az erôs vallásos meggyőződésűek ritkábban alkalmaznak folyamatos mély szedációt [30], illetve a beteggel az élet megrövidítéséről való kommunikáció gyakoribb az ateista orvosok esetében [17]. Vizsgálatunk alátámasztja a korábbi tanulmányok eredményét: a vallásukat gyakorló ápolók inkább folytatnák a beteg kezelését a hozzátartozó kérése ellenére is, ha még látnának esélyt a gyógyulásra, mint a vallásukat nem gyakorló és ateista társaik. Az orvosok esetében ennél a kérdésnél nem találtunk szignifikáns eltérést.

Az életmentő és életfenntartó kezelések egyoldalú orvosi korlátozása a szekularizált államokban - a hasztalanság bizonytalan eseteit kivéve - etikailag és jogilag egyaránt elítélendő. A modern etika és a jog egyik alapelve a beteg autonómiája, ennek biztosításához a beteget tájékoztatni kell állapotáról, a kezelés felfüggesztéséről hozott döntésbe pedig a hatályos etikai és jogszabályok szerint be kell vonni. Az egészségügyrôl szóló 1997. évi CLIV. törvény 13. $\$$-a meghatározza a betegek tájékoztatáshoz való jogát [32], a 15-23. \$ az önrendelkezéshez és az ellátás visszautasításának jogát részletezi. Eszerint cselekvőképes betegnek jogában áll közokiratban, teljes bizonyító erejű magánokiratban, illetve írásképtelen állapotában két tanú előtt az ellátást visszautasítani. 
Életfenntartó vagy életmentő kezelés visszavonását azonban a törvény csak szigorúan meghatározott feltételek (rövid időn belül halálhoz vezető, gyógyíthatatlan betegek) esetében teszi lehetővé. A jogalkotók nem tértek ki a hasztalan kezelés és a kezeléskorlátozás szabályozására. Az egészségügyi törvény 22 . \$-a lehetőséget biztosít a cselekvőképes betegnek későbbi cselekvőképtelensége esetére közokiratban visszautasítania vizsgálatokat, beavatkozásokat, azonban az előzetes rendelkezés a bonyolult alaki feltételek miatt hazánkban rendkívül ritkán érvényesül. Tekintettel arra, hogy az intenzív osztályon kezelt betegek az állapotukból kifolyólag ritkán tudnak beleszólni kezelésükbe, az élő végrendelet elterjesztésére, a hozzátartozók tájékoztatására és részvételére az életvégi döntésekben nagyobb hangsúlyt kell helyezni $[33,34]$.

Jelen vizsgálatunk nem a helytelen gyakorlatot, hanem az arról kialakított véleményt elemezte. Vizsgáltuk, hogy hazánkban mennyire érvényesül a tájékoztatáshoz való jog az intenzív osztályokon. A betegek és hozzátartozók tájékoztatása orvosi feladat, vizsgálatunk ennél a kérdéskörnél is az ápolók hozzáállását tükrözi. Ha már nem látnának esélyt a gyógyulásra, az ápolók 84\%-a tájékoztatná, 5\%-a nem tájékoztatná, 11\%-a az orvosra bízná a felvilágosítást; az orvosok 83,8\%-a tájékoztatná, 7,57\%-a nem tájékoztatná a hozzátartozót a beteg állapotáról az életvégi döntés meghozatala előtt. A tájékoztatás és a vallásosság között nem találtunk összefüggést, azonban a kezeléskorlátozásról hozott döntés során a gyakorló hívő orvosokat szignifikánsan jobban befolyásolta a hozzátartozók véleménye, mint a vallásukat nem gyakorló és ateista orvosokat.

\section{Következtetés}

Vizsgálatunk alátámasztotta, hogy mind az orvosok és ápolók, mind a betegek világnézete hatással lehet az életvégi döntésekre. Fontos, hogy a kezelőszemélyzet a vonatkozó etikai és jogszabályok keretei közt ne csupán saját hite szerint döntsön, hanem vegye figyelembe a beteg/család kulturális hátterét, vallásosságát és az egyén saját értékrendjét.

A vallással kapcsolatos téma még napjainkban is tabunak számít. Az anonim kérdőív ellenére a kérdőívet kitöltő orvosok 18\%-a, az ápolók 29\%-a nem adott a vallásosságra vonatkozó kérdésre választ, a Központi Statisztikai Hivatal 2011. évi népszámlálása során kapott adatokhoz hasonlóan. Feltehetőleg az orvos-beteg kommunikáció során még kisebb arányban beszélnek róla. Éppen ezért tartjuk fontosnak a vizsgálat során kapott eredmények ismertetését, valamint további multicentrikus vizsgálatok elvégzését a vallásosság és az életvégi döntések közötti kapcsolat feltárására, a szakemberek oktatását és a párbeszédet, hiszen a téma sokakat érint, mégsem beszélünk róla nyíltan.

A vizsgálat korlátai: Tanulmányunk korlátai közé tartozik, hogy a kérdőív kitöltése önkéntes volt. A vizsgálat- ban magyarországi intenzív osztály dolgozói vettek részt. A válaszadási arány relatíve alacsony volt, mivel nem alkalmaztunk ismételt megkeresést, így az eredmények nem tekinthetők reprezentatívnak. Vizsgálatunk során nem kérdeztünk rá a felekezeti hovatartozásra, mivel nem számítottunk a populációtól való jelentős eltérésre. Az orvosok és az ápolók vallásosságát mértük fel, nem vizsgáltuk a betegek hitét, sem a felekezeti hovatartozást. Nem vettek részt neonatalis intenzív osztály dolgozói a kérdőív kitöltésében. Publikációnk 2011-ben készült vizsgálat adataira támaszkodik.

Anyagi támogatás: A közlemény megírása és a kutatómunka anyagi támogatásban nem részesült.

Szerzői munkamegosztás: Sz. O., Z. L., É. G., Sz. L.: A kérdőívek szerkesztése, feldolgozása, a hipotézisek kidolgozása, a vizsgálat lefolytatása, a kézirat megszövegezése. K. K.: Statisztikai elemzés. D. K., Sz. A., G. J.: A kézirat ellenőrzése, végső formába öntése. A cikk végleges változatát valamennyi szerző elolvasta és jóváhagyta.

Érdekeltségek: A szerzőknek nincsenek érdekeltségeik.

\section{Köszönetnyilvánítás}

Köszönetünket fejezzük ki minden orvosnak és szakdolgozónak, aki a kérdőívek kitöltésével segített minket a felmérés elkészítésében.

\section{Irodalom}

[1] Jobbágyi G. Euthanasia I. [Eutanázia, I. rész] Magy Szle. 2004; 13(5-6): 6-32. [Hungarian]

[2] Hippocrates. Hippocratic oath. Late 5th century BC

[3] Garcia B, Brind'Amour K. "Evangelium vitae (1995), by Pope John Paul. II." Embryo Project Encyclopedia, Arizona State University, 11. 11. 2007

[4] Catholic Church declaration on euthanasia. Sacred Congregation for the doctrine of the faith declaration on euthanasia. Roma, 1980.

[5] Sharp S, Carr D, Macdonald C. Religion and end-of-life treatment preferences: assessing the effects of religious denomination and beliefs. Social Forces 2012; 91: 275-298.

[6] Ganz FD, Benbenishty J, Hersch M, et al. The impact of regional culture on intensive care end of life decision making: an Israeli perspective from the ETHICUS study. J Med Ethics 2006; 32: 196-199.

[7] Bülow HH, Sprung CL, Reinhart K, et al. The world's major religions' points of view on end-of-life decisions in the intensive care unit. Intensive Care Med. 2008; 34: 423-430.

[8] Leong M, Olnick S, Akmal T, et al. How Islam influences endof-life care: education for palliative care clinicians. J Pain Symptom Manage. 2016; 52: 771-774.e3.

[9] Sengupta J, Chatterjee, SC. Dying in intensive care units of India: commentaries on policies and position papers on palliative and end-of-life care. J Crit Care 2016; 39: 11-17.

[10] Chan TW, Poon E, Hegney DG. What nurses need to know about Buddhist perspectives of end-of-life care and dying. Progr Palliat Care 2011; 19: 61-65. 
[11] Blasszauer B. Churches' opinion on euthanasia. In: Blasszauer B. Euthanasia. [Az egyházak véleménye az eutanáziáról. In: Blasszauer B. Eutanázia.] Medicina Könyvkiadó, Budapest, 1997; pp. 107-130. [Hungarian]

[12] Cook S, Peden C. Cultural issues in end-of-life care. Update Anaesth. 2012; 28: 243-246.

[13] Angus DC, Barnato AE, Linde-Zwirble, WT, et al. Use of intensive care at the end of life in the United States: an epidemiologic study. Crit Care Med. 2004; 32: 638-643.

[14] Bulow HH, Sprung CL, Baras M, et al. Are religion and religiosity important to end-of-life decisions and patient autonomy in the ICU? The Ethicatt study. Intensive Care Med. 2012; 38: $1126-1133$

[15] Sprung CL, Maia P, Bulow HH, et al. The importance of religious affiliation and culture on end-of-life decisions in European intensive care units. Intensive Care Med. 2007; 33: 1732-1739.

[16] Kinsella J, Booth MG. Ethical framework for end of life decisions in intensive care in the UK. J Natl Inst Public Health 2007; 56: 387-392.

[17] Seale C. The role of doctors' religious faith and ethnicity in taking ethically controversial decisions during end-of-life care. J Med Ethics 2010; 36: 677-682.

[18] Editorial. Physician, know thyself. Lancet 2010; 376: 743.

[19] Siegel MD. End-of-life decision making in the ICU. Clin Chest Med. 2009; 30: 181-194.

[20] Sulmasy DP. Spiritual issues in the care of dying patients: “...it's okay between me and god". JAMA 2006; 296: 1385-1392.

[21] Winter L. Patient values and preferences for end-of-life treatments: are values better predictors than a living will? J Palliat Med. 2013; 16: 362-368.

[22] Moale AC, Rajasekhara S, Ueng W, et al. Educational intervention enhances clinician awareness of Christian, Jewish, and Islamic teachings around end-of-life care. J Palliat Med. 2019; 22: 62-70.

[23] Miccinesi G, Fischer S, Paci E, et al. Physicians' attitudes towards end-of-life decisions: a comparison between seven countries. Soc Sci Med. 2005; 60: 1961-1974.

[24] Ntantana A, Matamis D, Savvidou S, et al. The impact of healthcare professionals' personality and religious beliefs on the decisions to forego life sustaining treatments: an observational, mul- ticentre, cross-sectional study in Greek intensive care units. BMJ Open 2017; 7: e013916.

[25] Van der Heide A, Deliens L, Faisst K, et al. End-of-life decisionmaking in six European countries: descriptive study. Lancet 2003 ; 362: 345-350.

[26] Vincent JL. Cultural differences in end-of-life care. Crit Care Med. 2001; 29(2 Suppl): N52-N55.

[27] Doron D, Wexler ID, Shabtai E, et al. Israeli dying patient act: physician knowledge and attitudes. Am J Clin Oncol. 2014; 37: 597-602.

[28] Karches KE, Chung GS, Arora V, et al. Religiosity, spirituality, and end-of-life planning: a single-site survey of medical inpatients. J Pain Symptom Manage. 2012; 44: 843-851.

[29] Kranidiotis G, Gerovasili V, Tasoulis A, et al. End-of-life decisions in Greek intensive care units: a multicenter cohort study. Crit Care 2010; 14: R228.

[30] Löfmark R, Nilstun T, Cartwright C, et al. Physicians' experiences with end-of-life decision-making: survey in 6 European countries and Australia. BMC Med. 2008; 6: 4.

[31] Hungarian Central Statistical Office. National Census 2011. 10. Religion and denomination. [Központi Statisztikai Hivatal. Népszámlálás 2011. - 10. Vallás, felekezet.] Központi Statisztikai Hivatal, Budapest, 2014. Available from: www.ksh.hu/nepszamlalas/vallas [accessed: June 15, 2021]. [Hungarian]

[32] Act CLIV of 1997 on health. [1997. évi CLIV. törvény az egészségügyről.] Available from: https://net.jogtar.hu/ jogszabaly?docid=99700154.tv [accessed: June 15, 2021]. [Hungarian]

[33] Zubek L. Options for the improvement of communication and self-determination in end-of-life decisions in intensive care units. [A kommunikáció és az önrendelkezés javításának lehetőségei az életvégi döntések meghozatalánál az intenzív osztályokon.] Orv Hetil. 2016; 157: 669-674. [Hungarian]

[34] Zubek L, Szabó L, Gál J, et al. Practice of treatment restriction in Hungarian intensive care units. [A kezeléskorlátozás gyakorlata a hazai intenzív osztályokon.] Orv Hetil. 2010; 151: 15301536. [Hungarian]

(Szücs Orsolya dr., Budapest, Üllői út 78., 1082 e-mail: szucs.orsolya@med.semmelweis-univ.hu)

\section{"Caeci sunt oculi cum animus alias res agit." (A szem vak, míg a lélek másra figyel.)}

A cikk a Creative Commons Attribution 4.0 International License (https://creativecommons.org/licenses/by/4.0/) feltételei szerint publikált Open Access közlemény, melynek szellemében a cikk bármilyen médiumban szabadon felhasználható, megosztható és újraközölhető, feltéve, hogy az eredeti szerző és a közlés helye, illetve a CC License linkje és az esetlegesen végrehajtott módosítások feltüntetésre kerülnek. (SID_1) 